\title{
Development of QSAR model for immunomodulatory activity of natural coumarinolignoids
}

This article was published in the following Dove Press journal:

Drug Design, Development and Therapy

29 July 2010

Number of times this article has been viewed

\section{Dharmendra K Yadav \\ Abha Meena \\ Ankit Srivastava \\ D Chanda \\ Feroz Khan \\ SK Chattopadhyay}

Metabolic and Structural Biology Department, Central Institute of Medicinal and Aromatic Plants,

Council of Scientific and Industrial Research, PO-CIMAP, India
Correspondence: Feroz Khan Metabolic and Structural Biology Department, Central Institute of Medicinal and Aromatic Plants, Council of Scientific and Industrial Research, PO-CIMAP, Kukrail Picnic Spot Road, Lucknow-2260I5 (UP), India

Tel +9l-522-27I 7434 , ext 259

Fax +91 5222342666

Email f.khan@cimap.res.in
Abstract: Immunomodulation is the process of alteration in immune response due to foreign intrusion of molecules inside the body. Along with the available drugs, a large number of herbal drugs are promoted in traditional Indian treatments, for their immunomodulating activity. Natural coumarinolignoids isolated from the seeds of Cleome viscose have been recognized as having hepatoprotective action and have recently been tested preclinically for their immunomodulatory activity affecting both cell-mediated and humoral immune response. To explore the immunomodulatory compound from derivatives of coumarinolignoids, a quantitative structure activity relationship (QSAR) and molecular docking studies were performed. Theoretical results are in accord with the in vivo experimental data studied on Swiss albino mice. Immunostimulatory activity was predicted through QSAR model, developed by forward feed multiple linear regression method with leave-one-out approach. Relationship correlating measure of QSAR model was $99 \%\left(R^{2}=0.99\right)$ and predictive accuracy was $96 \%\left(\mathrm{RCV}^{2}=0.96\right)$. QSAR studies indicate that dipole moment, steric energy, amide group count, lambda max (UV-visible), and molar refractivity correlates well with biological activity, while decrease in dipole moment, steric energy, and molar refractivity has negative correlation. Docking studies also showed strong binding affinity to immunomodulatory receptors.

Keywords: coumarinolignoids, immunomodulation, docking, QSAR, regression model

Immunomodulation is the process of alteration in immune response due to foreign intrusion of molecules inside the body. It can be either immunostimulative or immunosuppressive. Along with the available drugs, a large number of herbal drugs are mentioned in Ayurveda (a traditional system of Indian medicine), for their immunomodulating activity. ${ }^{1-2}$ In the past, living and attenuated microorganisms' autologous and heterologous proteins and injections of animal organ preparations were used with the aim of restoring an impaired defense mechanism. At present thymus peptides and other biological response modifiers (BRM) (eg, interferon, interleukines), synthetic low molecular weight compounds (eg, Levamisole), chemically modified nucleotides, polysaccharides from fungi (eg, Lentinan), and, especially in Europe and Asia, some plant extracts, are also used for the same purpose.

Many medicinal plant products have been reported to show immunomodulatory effects, such as barberin, boswellic acid, aristolochic acid, cichoric acid, and plumbagin. ${ }^{2}$ Natural coumarinolignoids are also among the biologically active compounds which have shown promising immunomodulatory activity affecting both cell mediated and humoral immune response. ${ }^{3-5}$ Cleomiscosins are the natural coumarinolignoids extracted from an annual herb Cleome viscosa (syn. C. icosandra), a common weed of the family Capparidaceae and they have been used in the traditional systems of 
Indian medicine. Considerable phytochemical work on different parts of this plant have been studied well. ${ }^{3-5}$ These are newly identified class of natural products in which a lignan group $\left(\mathrm{C}_{6} \mathrm{C}_{3}\right.$ unit) is linked with a coumarin moiety through a dioxane bridge. ${ }^{5}$ Coumarinolignoids belong to the cycloalkylpropanoic acid class of compounds. Attachment of a phenylpropane unit with a polyphenolic compound through a dioxin bridge was earlier witnessed in the flavono-lignoid, silybin, xanthono-lignoid, and kielcorin. ${ }^{5}$ Cleomiscosins are the members of coumarino-lignoids and represent a new class of lignans called coumarinolignans. The isolated compounds showed immunomodulatory effect on Swiss albino mice, weighing $16-21 \mathrm{~g}$ with $\mathrm{LD}_{50}$ value $>100 \mu \mathrm{M} / \mathrm{L}$ for racemic mixture of three cleomiscosin molecules viz., A, B, and C. ${ }^{4}$

In the present study, we screen out potential anti-inflammatory and immunomodulatory compound cleomiscosin-B from the isolated racemic mixture of three cleomiscosin isoforms through quantitative structure activity relationship (QSAR) and molecular docking studies. On the basis of binding affinity energy, possible immunomodulatory receptors were identified. For the structural activity relationship, a multiple linear QSAR regression model was developed which successfully establishes the immunomodulatory activity of coumarinolignoids in accord with the in vivo experimental data. ${ }^{4}$ QSAR modeling also furnishes the activity dependent structural descriptors and predicts the effective dose of other derivatives, thereby suggesting the possible toxicity range. The relationship correlating measure of QSAR model was $99 \%\left(R^{2}=0.99\right)$ and predictive accuracy was $96 \%\left(\mathrm{RCV}^{2}=0.96\right)$. Druggability of studied compounds was evaluated using Lipinsky's 'Rule of Five' and in silico ADME analysis through bioavailability filters. QSAR studies indicate that dipole moment, steric energy, amide group count, lambda max UV-visible, and molar refractivity correlate well with anti-inflammatory and immunomodulatory activity. These results could offer useful references for understanding mechanisms and directing the molecular design of lead compounds with improved immunomodulatory activity.

\section{Materials and methods}

Isolation and in vivo immunomodulatory activity of coumarinolignoids

The chemical and structural determination of studied coumarinolignoid derivatives from $C$. viscosa have been studied using IR Spectra and nuclear magnetic resonance (NMR) techniques. Isolation and in vivo anti-inflammatory and immunomodulatory activity of coumarinolignoids from $C$. viscosa seeds have been carried out in the past by
Bawankule et al. ${ }^{4}$ Anti-inflammatory and immunomodulatory activity of coumarinolignoids was studied in a lipopolysaccharide- (LPS) induced toxicity model in Swiss albino mice, weighing 16-21 g. Proinflammatory mediators such as cytokines, interleukin-6 (IL-6), or tumor necrosis factor- $\alpha$ (TNF- $\alpha$ ) and nitric oxide (NO) were estimated from culture supernatant obtained from peritoneal macrophages stimulated by LPS and anti-inflammatory mediator IL-4 was estimated from culture supernatant obtained from spleenocytes stimulated by concavalin-A (Con-A). For further confirmation, expressions of inflammatory mediators from serum and mortality rate were studied in an LPS-induced toxicity model in mice. Proinflammatory mediator's expression was significantly decreased in the treatment group in a dose-dependent manner, whereas the anti-inflammatory mediator expression was significantly increased at $10 \mathrm{mg} / \mathrm{kg}$ treatment. Mortality rate was also significantly reduced in the treatment group in the LPS-induced toxicity model. ${ }^{4}$

\section{Structure cleaning, optimization, and molecular docking}

The structures of coumarinolignoid derivatives were constructed using the Scigress Explorer v7.7.0.47 (Fujitsu Ltd., Tokyo, Japan) workspace module. The optimization of the cleaned molecules was done through MO-G computational application that computes and minimizes an energy related to the heat of formation. The MO-G computational application solves the Schrodinger equation for the best molecular orbital and geometry of the ligand molecules. The augmented Molecular Mechanics (MM2/MM3) parameter was used for optimizing the molecules up to its lowest stable energy state. This energy minimization is done until the energy change is less than $0.001 \mathrm{kcal} / \mathrm{mol}$ or the molecules are updated almost 300 times. However, the chemical structures of known drugs were retrieved through the PubChem compound database at NCBI (http://www.pubchem.ncbi.nlm.nih.gov). Crystallographic 3D structures of Human's target proteins were retrieved through Brookhaven protein databank (http://www. pdb.org). The valency and hydrogen bonding of the ligands as well as target proteins were subsequently satisfied through the Workspace module. Hydrogen atoms were added to protein targets for correct ionization and tautomeric states of amino acid residues such as His, Asp, Ser, and Glu. Molecular docking of the drugs and the isolated coumarinolignoid derivatives, especially cleomiscosin molecules (A, B, and C), with the immunomodulatory receptors was done using the Fast-DockManager and Fast-Dock-Compute engines available with the Project-leader module of Scigress Explorer (7.7.0.47; Fujitsu 
Ltd., Tokyo, Japan). For automated docking of ligands into the active sites we used genetic algorithm with a fast and simplified Potential of Mean Force (PMF) scoring scheme. ${ }^{6-7}$ PMF uses atom types which are similar to the empirical force fields used in Mechanics and Dynamics. A minimization is performed by the Fast-Dock engine which uses a Lamarkian genetic algorithm (LGA) so that individuals adapt to the surrounding environment. The best fits are sustained through analyzing the PMF scores of each chromosome and assigning more reproductive opportunities to the chromosomes having lower scores. This process repeats for almost 3,000 generations with 500 individuals and 100,000 energy evaluations. Other parameters were left to their default values. Structure-based screening involves docking of candidate ligands into protein targets, followed by applying a PMF scoring function to estimate the likelihood that the ligand will bind to the protein with high affinity or not..$^{7-8}$

\section{Selection of chemical descriptors for QSAR modeling}

For identifying the immunomodulatory activity of the coumarinolignoid derivatives, QSAR study was performed. A total of 52 chemical properties (descriptors) were used for QSAR model development. A total of 61 drugs were involved and lethal dose was considered as the biological activity parameter of the compounds. Forward feed multiple linear regression mathematical expression was then used to predict the biological response of other derivatives. QSAR analysis is a mathematical procedure by which the chemical structures of molecules is quantitatively correlated with a well defined parameter, such as biological activity or chemical reactivity. For example, biological activity can be expressed quantitatively as in the concentration of a substance required to give a certain biological response. Additionally, when physicochemical properties or structures are expressed by numbers, one can form a mathematical relationship, or quantitative structure-activity relationship, between the two. The mathematical expression can then be used to predict the biological response of other chemical structures. QSAR's most general mathematical form is:

\section{Activity $=\mathrm{f}$ (physiochemical properties and/or structural properties)}

A QSAR model attempts to find consistent relationships between the variations in the values of molecular properties and the biological activity for a series of compounds which can then be used to evaluate properties of new chemical entities..$^{9,23}$
Before the novel compounds can be used as potential drugs, the prediction of toxicity/activity ensures the calculation of risk factors associated with the administration of that particular drug. A QSAR model ultimately helps in predicting these important parameters in the form of $\mathrm{ED}_{50}$ or $\mathrm{LD}_{50}$ values. Some of the important chemical descriptors used in multiple linear regression analysis are: atom count (all atoms), atom count (carbon), atom count (hydrogen), atom count (oxygen), bond count (all bonds), conformation minimum energy (kcal/mole), connectivity index (order 0 , standard), connectivity index (order 1 , standard), connectivity index (order 2, standard), dipole moment (debye), dipole vector X (debye), dipole vector Y (debye), dipole vector Z (debye), electron affinity (eV), dielectric energy ( $\mathrm{kcal} / \mathrm{mole})$, steric energy ( $\mathrm{kcal} / \mathrm{mole})$, total energy (Hartree), group count (amine), group count (carboxyl), group count (ether), group count (hydroxyl), group count (methyl), heat of formation ( $\mathrm{kcal} /$ mole), HOMO energy (eV), ionization potential $(\mathrm{eV})$, lambda max UV-visible (nm), lambda max far-UV-visible (nm), LogP, LUMO energy (eV), molar refractivity, molecular weight, polarizability, ring count (all rings), size of smallest ring, size of largest ring, and solvent accessibility surface area $\left(\AA_{2}\right)$.

\section{In silico druggability and ADME}

For analyzing druggability, Lipinski's rule of five pharmacokinetics filter was used as a drug likeness test. ${ }^{9}$ Briefly, this rule is based on the observation that most orally administered drugs have a molecular weight (MW) of 500 or less, a $\log \mathrm{P}$ no higher than 5 , five or fewer hydrogen bond donor sites, and 10 or fewer hydrogen bond acceptor sites ( $\mathrm{N}$ and $\mathrm{O}$ atoms). In addition, the bioavailability of all derivatives or test compounds was assessed through topological polar surface area analysis. We calculated the polar surface area (PSA) by using termed topological PSA (TPSA), based on the summation of tabulated surface contributions of polar fragments (ChemAxon-Marvinview 5.2.6:PSA plugin). ${ }^{10}$ Polar surface area (PSA) is formed by the polar atoms of a molecule. This descriptor was shown to correlate well with passive molecular transport through membranes and therefore allows prediction of transport properties of drugs and has been linked to drug bioavailability. Generally, passively absorbed molecules with a PSA $>140 \AA^{2}$ are thought to have low oral bioavailability. ${ }^{11}$ Calculation of other important absorption, distribution, metabolism, and excretion (ADME) properties of studied compounds was done through QikProp software (version 3.2; Schrödinger, LLC, New York, NY). 


\section{Results and discussion Chemical structure-activity relationship (SAR)}

In the present work, 12 derivatives of natural coumarinolignoids were evaluated for their anti-inflammatory and immunomodulatory activity through QSAR, ADME, and docking studies. Later results were compared with experimental in vivo activity data, which suggest that only three derivatives of coumarinolignoids (compound 1a, 1f, and 2a) have good anti-inflammatory and immunomodulatory activity. Results of the SAR study suggest in compound 1a (cleomiscosinA), the phenolic and alcoholic-OH groups in its molecule are responsible for its activity. ${ }^{3}$ The presence of a coumarin moiety based on other SAR studies on cleomiscosin-A (1a) has already been well established. ${ }^{3}$ Cleomiscosin-C (1f) has an extra -OMe group in the phenylpropanoid unit, and thus it showed less activity. It was found that the resonances for compound-1 $\mathrm{f}$ were in good agreement with those for $1 \mathrm{a}$, rather than those for $2 \mathrm{a}$ (cleomiscosin-B), especially in the chemical shifts for C-7', C-8', and C-9', which were most affected by the structural difference between $1 \mathrm{f}$ and $2 \mathrm{f}$. Compound $1 \mathrm{f}$ is a racemic compound and therefore has the same structural framework as 1a. Compound $2 \mathrm{a}$ (cleomiscosin-B) is the position isomeric compound of $1 \mathrm{a}$ and shows striking resemblance with 1a in all its spectral properties, indicating a close structural similarity, thus become most active derivative. The two oxide linkages in compound 2a are at C-7 and C-8 as in 1a (Figures 1-3). Later in vivo immunomodulatory biological activity of these compounds was tested on Swiss mice. ${ }^{4}$ Since in vivo activity was done on the racemic mixture of cleomiscosin A, $\mathrm{B}$ and $\mathrm{C}$, compounds (compound 1a, 1f, and 2a), in the present work we tried to explore the most active compound in the mixture based on QSAR modeling, molecular docking, and in silico ADME analysis. Results indicate that all compounds produce significant anti-inflammatory and immunomodulatory activity similar to that of the standard drug aristolochic acid. Compound 2a (cleomiscosin-B) exhibits strong anti-inflammatory and immunomodulatory activity, while compound 1a (cleomiscosin-A) exhibits the least activity. In vivo dosedependent experimental data for immunomodulatory effect of studied compounds are summarized in Table 1.

\section{Quantitative structure-activity relationship (QSAR) modeling}

Structure activity relationship has been denoted by QSAR model showing significant activity-descriptors relationship accuracy of $99 \%\left(R^{2}=0.99\right)$ and activity prediction accuracy of $96 \%\left(\mathrm{RCV}^{2}=0.96\right)$. A total of 61 drugs were used for QSAR modeling against 52 chemical descriptors. Only five descriptors were found to be significant and seem to be responsible for in vivo immunomodulatory activity (Table 2). A forward feed multiple linear regression QSAR model was developed using leave-one-out approach for the prediction of biological activity of cleomiscosin molecules. Anti-inflammatory and immunomodulatory drugs fit well into this correlation, which intuitively seems very reasonable. Results indicate that variations in stereochemistry do not markedly affect the binding energy of ligand and receptor. Therefore, we looked for a simpler descriptor for the prediction of biological in vivo activity for studied class of compounds. QSAR studies indicate that dipole moment, steric energy, amide group count, lambda max (UV-visible), and molar refractivity correlate well with biological activity (Table 2). The QSAR mathematical model equation derived through multiple linear regression method is given below, showing relationship between in vivo experimental activity $\left(\mathrm{LD}_{50}\right)$ and dependent five chemical descriptors:

Predicted $\log \mathrm{LD}_{50}(\mathrm{mg} / \mathrm{kg})=-0.156436 *$ dipole moment (debye) $-0.00118794 *$ steric energy $(\mathrm{kcal} / \mathrm{mole})+0.910351 *$ group count (amide) $+0.0206362 *$ lambda max UV-visible (nm) $-0.00834447 *$ molar refractivity -1.06753 .

$$
\left[\mathrm{RCV}^{2}=0.96(96 \%) \text { and } R^{2}=0.99(99 \%)\right]
$$

Since experimental in vivo activity was reported for racemic mixture of three cleomiscosin molecules $\mathrm{A}, \mathrm{B}$, and $\mathrm{C}$ (1a, 2a, and 1f) ie, $100 \mathrm{mg} / \mathrm{kg}$ (Table 1), we therefore aimed to predict the activity of each compound separately through QSAR modeling and identify the most active compound. We successfully developed the QSAR model for both antiinflammatory and immunomodulatory activity. More than 50 known drugs with reported anti-inflammatory as well as immunomodulatory activity were included in the training data set for comparison and evaluation of prediction accuracy of QSAR model. Results showed that predicted activity of cleomiscosin molecules (A, B, and C) were comparable with experimental activity. Results indicate that cleomiscosin-B (2a) had higher immunomodulatory activity than cleomiscosin-C (1f) and cleomiscosin-A (1a). Moreover, based on the results of molecular docking, cleomiscosin-B showed much better binding energy with immunomodulatory receptors, and is therefore considered as the most active compound in the coumarinolignoids mixture. We also checked the compliance of isolated compounds to Lipinski's 
<smiles>[R]OC[C@H]1Oc2c(c(OC)cc3ccc(=O)oc23)O[C@@H]1c1cc([R])c([R20])c(OC)c1</smiles>

Prototype-1<smiles>COc1ccc(C2Oc3c(c(OC)cc4ccc(=O)oc34)O[C@@H]2C=O)cc1OC</smiles>

Prototype-2

\begin{tabular}{|c|c|c|c|c|}
\hline Derivative & $\mathbf{R}$ & $\mathbf{R} 1$ & $\mathbf{R} 2$ & Name \\
\hline $1 \mathrm{a}$ & $\mathrm{H}$ & $\mathrm{H}$ & $\mathrm{H}$ & Cleomiscosin- $A^{*}$ \\
\hline $1 b$ & $\mathrm{H}$ & $\mathrm{Me}$ & $\mathrm{H}$ & Monomethyl ether \\
\hline $1 c$ & $\mathrm{H}$ & Et & $\mathrm{H}$ & Monoethyl ether \\
\hline $1 d$ & Ac & Ac & $\mathrm{H}$ & Diacetate \\
\hline $1 e$ & Ac & Et & $\mathrm{H}$ & Monoacetate \\
\hline $1 f$ & $\mathrm{H}$ & $\mathrm{H}$ & OMe & Cleomiscosin- $C^{*}$ \\
\hline $2 a$ & $\mathrm{H}$ & $\mathrm{H}$ & $\mathrm{H}$ & Cleomiscosin- $\mathrm{B}^{*}$ \\
\hline $2 b$ & $\mathrm{H}$ & $\mathrm{Me}$ & $\mathrm{H}$ & Monomethyl ether \\
\hline $2 c$ & $\mathrm{H}$ & Et & $\mathrm{H}$ & Monoethyl ether \\
\hline $2 d$ & Ac & Ac & $\mathrm{H}$ & Diacetate \\
\hline $2 e$ & $\mathrm{H}$ & $\mathrm{H}$ & $\mathrm{OH}$ & Hydroxy derivative \\
\hline $2 f$ & $\mathrm{H}$ & $\mathrm{H}$ & $\mathrm{OMe}$ & Methoxy derivative \\
\hline
\end{tabular}

Figure I Molecular differences in different coumarinolignoids derivatives. Prototype I and 2 are showing fusion of coumarin moiety with the phenylpropanoid unit (C6C3). Bold face indicates active and isolated compounds. Asterisk indicates that compounds were isolated as racemic mixture.<smiles>COc1cc(C2Oc3c(OC)cc4ccc(=O)oc4c3OC2CO)ccc1O</smiles>

$1 a$<smiles>COc1cc(C2Oc3c(OC)cc4ccc(=O)oc4c3OC2CO)cc(OC)c1O</smiles>

if Cleomiscosin C<smiles>COc1cc(C2Oc3c(OC)cc4ccc(=O)oc4c3OC2CO)ccc1O</smiles>

$2 a$

Cleomiscosin B

Figure 2 Molecular structure of the purified active natural coumarinolignoids isoforms la (Cleomiscosin-A), If (Cleomiscosin-C), and 2a (Cleomiscosin-B) isolated from the seeds of $C$. viscosa. 


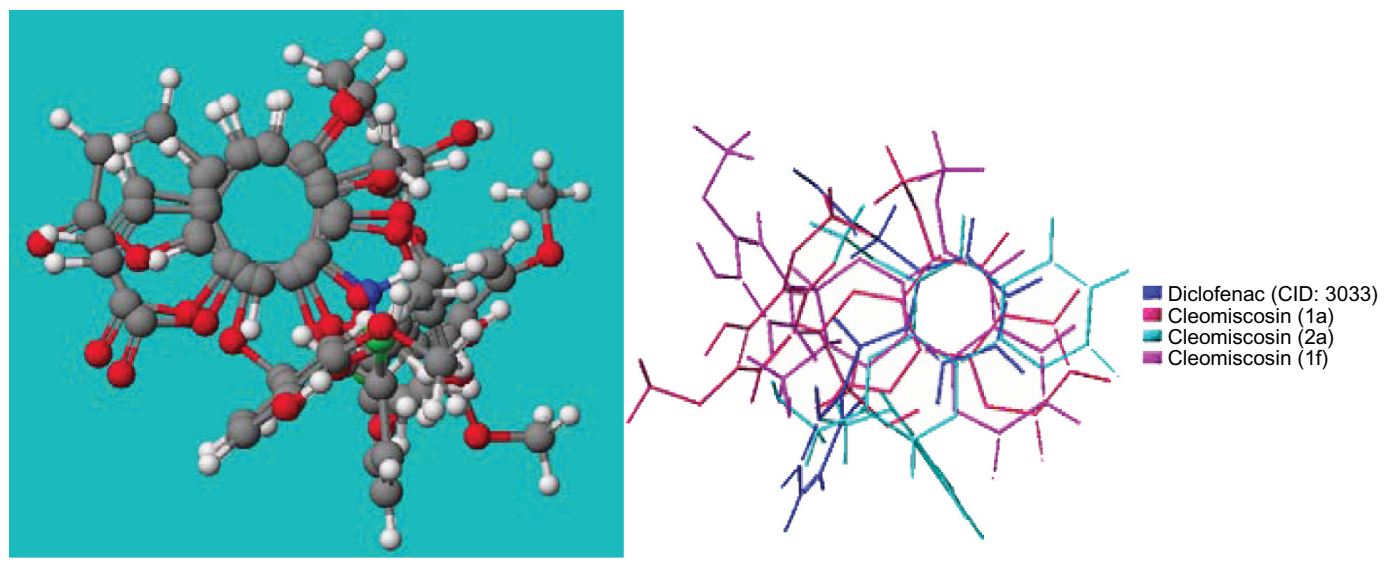

\begin{tabular}{|l|l|l|l|l|}
\hline \multirow{2}{*}{ Compd. } & \multicolumn{4}{l}{ Distance RMS $(\AA)$} \\
\cline { 2 - 5 } & $1 \mathrm{a}$ & $2 \mathrm{a}$ & $1 \mathrm{f}$ & Diclofenac \\
\hline $1 \mathrm{a}$ & 0 & 1.612 & 1.173 & 0.7942 \\
\hline $2 \mathrm{a}$ & 1.612 & 0 & 1.893 & 1.3895 \\
\hline $1 \mathrm{f}$ & 1.173 & 1.893 & 0 & 1.390 \\
\hline Diclofenac & 0.7942 & 1.306 & 1.390 & 0 \\
\hline
\end{tabular}

Figure 3 Superimposition of most favorable conformations of compounds Ia, 2a, If, and diclofenac docked into binding site of COX-2 receptor showing common pharmacophore ring structure.

rule-of-five for drug likeness (Table 3). Results indicate that isolated compounds follow most of the ADME properties, thus leading to a good drug candidate for anti-inflammatory and immunomodulatory activity (Table 4). This helped in establishing the pharmacological activity of these isolated novel compounds for their use as potential drugs. Moreover, when we calculated the topological polar surface area (TPSA) as a chemical descriptor for passive molecular transport through membranes, results showed higher TPSA of isolated compounds than standard drugs but within acceptable

Table I In vivo experimental anti-inflammatory and immunomodulatory activity data of isolated mixture of cleomiscosin A, B, and $\mathrm{C}$ molecules

\begin{tabular}{lll}
\hline Treatment (in vivo oral dose) & Response \% & Mortality* \\
\hline Vehicle control & 0 & $0 / 6$ \\
LPS control & 100 & $6 / 6$ \\
Coumarinolignoids $(10 \mathrm{mg} / \mathrm{kg})+$ LPS & 17 & $1 / 6$ \\
Coumarinolignoids $(30 \mathrm{mg} / \mathrm{kg})+$ LPS & 67 & $4 / 6$ \\
Coumarinolignoids $(100 \mathrm{mg} / \mathrm{kg})+$ LPS & 50 & $3 / 6$ \\
\hline
\end{tabular}

Note: $*=$ No. of female Swiss albino mice $(n=6)$. range (Table 3). TPSA allows for prediction of transport properties of drugs and has been linked to drug bioavailability. Generally, it has been seen that passively absorbed molecules with a TPSA $>140 \AA^{2}$ are thought to have low oral bioavailability. ${ }^{11}$ On the basis of bioavailability scores, we concluded that isolated compounds have marked immunomodulatory activity but lower bioavailability as compared to standard drugs. Isolated compound cleomiscosin-B (2a) and cleomiscosin-C (1f) showed comparatively low TPSA than cleomiscosin-A (1a).

\section{Binding affinity of coumarinolignoids for immunomodulatory receptors}

The effect of coumarinolignoids when studied in Swiss albino mice for anti-inflammatory and immunomodulatory activity showed a significant decrease in the expression of pro-inflammatory mediators such as IL-6, TNF- $\alpha$, and nitric oxide in a dose-dependent manner. Also the expression of immunomodulatory mediator IL-4 was found to increase with cleomiscosin A, C, and B (1a, 1f, and 2a) 
Table 2 Comparison of experimental and predicted in vivo activity data calculated through QSAR modeling based on the five most highly correlated chemical descriptors

\begin{tabular}{|c|c|c|c|c|c|c|c|c|}
\hline Drug/compound & $\begin{array}{l}\operatorname{Exp} L_{50} \\
(\mathrm{mg} / \mathrm{kg})\end{array}$ & $\begin{array}{l}\operatorname{Exp} \\
\log L D_{50}\end{array}$ & $\begin{array}{l}\text { Pred } \\
\log L D_{50}\end{array}$ & $\begin{array}{l}\text { Dipole moment } \\
\text { (debye) }\end{array}$ & $\begin{array}{l}\text { Steric energy } \\
\text { (kcal/mol) }\end{array}$ & $\begin{array}{l}\text { Group count } \\
\text { (amide) }\end{array}$ & $\begin{array}{l}\text { Lambda max } \\
\text { UV-visible } \\
\text { (nm) }\end{array}$ & $\begin{array}{l}\text { Molar } \\
\text { refractivity }\end{array}$ \\
\hline Aristolochic acid & 81 & 1.91 & 1.91 & 9.48 & 32.21 & 0 & 252.40 & 85.12 \\
\hline Azimexon & 170 & 2.23 & 2.22 & 3.86 & 509.14 & I & 194.44 & 51.20 \\
\hline Bowellic acid & 5000 & 3.70 & 3.70 & 2.61 & I | 4.53 & 0 & 311.39 & 133.70 \\
\hline Ciamexon & 130 & 2.11 & 2.15 & 4.02 & 251.32 & 0 & 223.73 & 56.96 \\
\hline Cichoric acid & 1750 & 3.24 & 3.24 & 4.50 & -12.68 & 0 & 287.34 & 112.13 \\
\hline Emetin & 32 & $|.5|$ & 1.50 & 1.91 & 39.04 & 0 & |97.4| & 139.75 \\
\hline Imemixon & 150 & 2.18 & 2.16 & 5.94 & 134.83 & 0 & 220.48 & 28.47 \\
\hline Isopteropodin & 162 & 2.21 & 2.22 & 5.07 & 40.63 & 1 & 196.12 & 99.27 \\
\hline Levamisol & 180 & 2.26 & 2.26 & 4.12 & 27.81 & 0 & 218.54 & 60.74 \\
\hline Curcumin & 2000 & 3.30 & 3.71 & 3.74 & 5.20 & 0 & 302.16 & 103.42 \\
\hline Celecoxib & 2000 & 3.30 & 1.39 & 4.29 & 52.90 & 0 & 191.16 & 90.98 \\
\hline Calanolide & 800 & 2.90 & 3.17 & 4.97 & 8.49 & 0 & 285.83 & I04.II \\
\hline Acetylsalicylic & 200 & 2.30 & 2.47 & 1.58 & 5.49 & 0 & 201.60 & 43.95 \\
\hline Cortisol & 5120 & 3.71 & 2.07 & 3.42 & 75.13 & 0 & 221.89 & 97.49 \\
\hline Cyclophosphamide & 200 & 2.30 & 2.39 & 4.01 & -10.67 & 0 & 220.69 & 58.48 \\
\hline Cleomiscosin-A & $100 *$ & 2.00 & 1.50 & 6.28 & 5.29 & 0 & 211.49 & 97.37 \\
\hline Cleomiscosin-B & & & 1.44 & 4.27 & 5.87 & 0 & 193.71 & 97.37 \\
\hline Cleomiscosin-C & & & 1.49 & 5.18 & 5.76 & 0 & 205.71 & 103.84 \\
\hline Diclofenac & & 2.59 & 2.30 & 1.02 & 51.40 & 0 & 204.28 & 75.46 \\
\hline
\end{tabular}

*Anti-inflammatory and immunomodulatory activity data for racemic mixture of cleomiscosin-A, B, and C.

administration. The expressions of inflammatory mediators from serum and mortality rate were studied in an LPSinduced acute inflammation model. ${ }^{4}$ We predicted the orientations and binding affinities of caumarolignoids with proinflammatory proteins and others with the aim of determining which units interact better. We know that the innate immune recognition is mediated by a structurally diverse set of receptors that belong to several distinct protein families. Among them are humoral proteins circulating in the plasma, endocytic receptors expressed on the cell surface, and signaling receptors that can be expressed either on the cell surface or intracellularly. ${ }^{12}$ The proinflammatory cytokines such as IL-1, IL-6, or TNF- $\alpha$ have been found to contribute to a variety of inflammatory condition such as ischemic tolerance, ${ }^{13}$ rheumatoid arthritis, ${ }^{14}$ nephritis, ${ }^{15}$ and liver diseases. ${ }^{16}$ Nitric oxide generated through inducible NO synthase (iNOS) enzymatic activity has been found to be participating in various

Table 3 Compliance of compounds with computational parameters of drug likeness

\begin{tabular}{|c|c|c|c|c|c|c|c|}
\hline S No. & Compd & TPSA $\left(\mathbf{A}^{2}\right)$ & Molecular weight & $\log P$ & $\begin{array}{l}\text { H-bond donors } \\
\text { (OH group) }\end{array}$ & $\begin{array}{l}\text { H-bond acceptors } \\
\text { (O atom) }\end{array}$ & $\begin{array}{l}\text { No. of rule of } \\
\text { five violations }\end{array}$ \\
\hline I. & Diclofenac & 49.33 & 296.152 & 3.965 & 0 & 2 & 0 \\
\hline 2. & la & 91.29 & 386.357 & 1.822 & 2 & 8 & 0 \\
\hline 3. & $\mathrm{lb}$ & 74.22 & 400.384 & 1.853 & 1 & 8 & 0 \\
\hline 4. & Ic & 83.45 & $4|4.4| I$ & 2.196 & I & 8 & 0 \\
\hline 5. & Id & 106.59 & 502.431 & 2.276 & 0 & 12 & 2 \\
\hline 6. & le & 63.22 & 472.448 & 2.596 & 0 & 10 & 0 \\
\hline 7. & If & 83.45 & 416.384 & 1.569 & 2 & 9 & 0 \\
\hline 8. & $2 a$ & 83.45 & 386.357 & 1.821 & 2 & 8 & 0 \\
\hline 9. & $2 b$ & 72.45 & 400.384 & $\mathrm{I} .853$ & I & 8 & 0 \\
\hline 10. & $2 c$ & 72.45 & $4|4.4| I$ & 2.196 & I & 8 & 0 \\
\hline 11. & $2 d$ & 44.76 & 502.431 & 2.276 & 0 & 12 & 2 \\
\hline 12. & $2 e$ & 103.68 & 402.357 & 1.537 & 3 & 9 & 0 \\
\hline 13. & $2 f$ & 92.68 & 416.384 & 1.569 & 2 & 9 & 0 \\
\hline 14. & 3 & 101.91 & 460.48 & 2.554 & 0 & 9 & 0 \\
\hline 15. & 4 & 112.91 & 448.469 & 1.886 & I & 9 & 0 \\
\hline 16. & 5 & 106.91 & 386.357 & I.722 & 2 & 8 & 0 \\
\hline
\end{tabular}


Table 4 Compliance of compounds with computational parameters of ADME

\begin{tabular}{|c|c|c|c|c|c|c|}
\hline $\begin{array}{l}\text { Principal } \\
\text { descriptors }\end{array}$ & Levamisole & Aristolochic acid & Cleomiscosin-A & Cleomiscosin-B & Cleomiscosin-C & $\begin{array}{l}\text { (Range 95\% } \\
\text { of drugs) }\end{array}$ \\
\hline $\begin{array}{l}\text { Solute molecular } \\
\text { weight }\end{array}$ & 204.289 & 341.276 & 386.357 & 386.357 & 416.384 & $(130.0 / 725.0)$ \\
\hline $\begin{array}{l}\text { Solute dipole } \\
\text { moment (D) }\end{array}$ & 5.344 & $14.344 *$ & 8.366 & 10.631 & 7.109 & $(1.0 / / 2.5)$ \\
\hline $\begin{array}{l}\text { Solute total } \\
\text { SASA }\end{array}$ & 427.221 & 503.667 & 591.932 & 598.957 & 619.895 & $(300.0 / 1000.0)$ \\
\hline $\begin{array}{l}\text { Solute hydrophobic } \\
\text { SASA }\end{array}$ & 161.747 & 156.135 & 233.265 & 223.883 & 282.155 & $(0.0 / 750.0)$ \\
\hline $\begin{array}{l}\text { Solute hydrophilic } \\
\text { SASA }\end{array}$ & 26.205 & 164.026 & 177.359 & 163.462 & 173.297 & $(7.0 / 330.0)$ \\
\hline $\begin{array}{l}\text { Solute carbon } \\
\text { pi SASA }\end{array}$ & 191.048 & 183.506 & 181.307 & 211.612 & 164.443 & $(0.0 / 450.0)$ \\
\hline $\begin{array}{l}\text { Solute weakly } \\
\text { polar SASA }\end{array}$ & 48.22 & 0 & 0 & 0 & 0 & $(0.0 / 175.0)$ \\
\hline $\begin{array}{l}\text { Solute molecular } \\
\text { volume }\left(A^{\wedge} 3\right)\end{array}$ & 698.974 & 900.195 & $|084.06|$ & 1076.777 & 1161.989 & $(500 / 2000)$ \\
\hline $\begin{array}{l}\text { Solute vdW } \\
\text { Polar SA (PSA) }\end{array}$ & $|7.59|$ & || $0.83 \mid$ & 117.094 & 111.88 & 125.462 & $(7.0 / 200.0)$ \\
\hline $\begin{array}{l}\text { Solute No. of } \\
\text { rotatable bonds }\end{array}$ & 0 & 3 & 5 & 5 & 6 & $(0.0 / / 5.0)$ \\
\hline $\begin{array}{l}\text { Solute as donor - } \\
\text { hydrogen bonds }\end{array}$ & 0 & I & 2 & 2 & 2 & $(0.0 / 6.0)$ \\
\hline $\begin{array}{l}\text { Solute as acceptor - } \\
\text { hydrogen bonds }\end{array}$ & 2 & 5.25 & 7.95 & 7.95 & 8.7 & $(2.0 / 20.0)$ \\
\hline $\begin{array}{l}\text { Solute globularity } \\
(\text { sphere }=I)\end{array}$ & 0.892 & 0.895 & 0.862 & 0.848 & 0.862 & $(0.75 / 0.95)$ \\
\hline $\begin{array}{l}\text { Solute ionization } \\
\text { potential }(\mathrm{eV})\end{array}$ & 8.874 & 9.345 & 8.951 & 8.835 & 8.854 & $(7.9 / 10.5)$ \\
\hline $\begin{array}{l}\text { Solute electron } \\
\text { affinity }(\mathrm{eV})\end{array}$ & 0.381 & $2.484 *$ & $\mathrm{I} .546$ & 1.393 & 1.681 & $(-0.9 / 1.7)$ \\
\hline $\begin{array}{l}\text { Polarizability } \\
\left(\text { angstroms }{ }^{\wedge}\right)\end{array}$ & $23.643 M$ & $29.698 M$ & 35.751 & 35.749 & 38.067 & $(\mid 3.0 / 70.0)$ \\
\hline $\begin{array}{l}\text { log P for } \\
\text { hexadecane/gas }\end{array}$ & $6.610 \mathrm{M}$ & $9.430 \mathrm{M}$ & 11.315 & 11.330 & 11.880 & $(4.0 / / 8.0)$ \\
\hline $\begin{array}{l}\log P \text { for } \\
\text { octanol/gas }\end{array}$ & 8.972 & $17.260 \mathrm{M}$ & 19.997 & 20.480 & 20.872 & $(8.0 / 35.0)$ \\
\hline log $P$ for water/gas & 4.212 & $9.269 \mathrm{M}$ & 13.240 & 13.369 & 13.683 & $(4.0 / 45.0)$ \\
\hline $\begin{array}{l}\log P \text { for } \\
\text { octanol/water }\end{array}$ & 3.108 & 2.395 & 1.723 & 1.798 & 1.913 & $(-2.0 / 6.5)$ \\
\hline $\begin{array}{l}\log S \text { for aqueous } \\
\text { solubility }\end{array}$ & -3.476 & $-3.28 I$ & -3.553 & -3.664 & -3.613 & $(-6.5 / 0.5)$ \\
\hline $\begin{array}{l}\text { log S - conformation } \\
\text { independent }\end{array}$ & -3.064 & -5.011 & -4.962 & -4.962 & -5.262 & $(-6.5 / 0.5)$ \\
\hline $\begin{array}{l}\log K \text { hsa serum } \\
\text { protein binding }\end{array}$ & 0.112 & -0.194 & -0.12 & -0.15 & -0.099 & $(-1.5 / 1.5)$ \\
\hline $\begin{array}{l}\text { log BB for } \\
\text { brain/blood }\end{array}$ & 0.462 & -0.982 & -1.329 & -1.252 & -1.352 & $(-3.0 / 1.2)$ \\
\hline $\begin{array}{l}\text { No. of primary } \\
\text { metabolites }\end{array}$ & 2 & 2 & 5 & 5 & 6 & $(1.0 / 8.0)$ \\
\hline $\begin{array}{l}\text { Predicted CNS } \\
\text { activity }\end{array}$ & ++ & - & - & - & - & $\begin{array}{l}-2 \text { (inactive) } \\
+2 \text { (active) }\end{array}$ \\
\hline $\begin{array}{l}\text { HERG K+ channel } \\
\text { blockage: log IC50 }\end{array}$ & -4.198 & -2.296 & -4.627 & -4.997 & -4.545 & $\begin{array}{l}\text { (concern } \\
\text { below }-5 \text { ) }\end{array}$ \\
\hline $\begin{array}{l}\text { Apparent Caco-2 } \\
\text { permeability }(\mathrm{nm} / \mathrm{sec})\end{array}$ & 5589 & 69 & 206 & 279 & 225 & $\begin{array}{l}\text { ( }<25 \text { poor } \\
>500 \text { great) }\end{array}$ \\
\hline
\end{tabular}


Table 4 (Continued)

\begin{tabular}{|c|c|c|c|c|c|c|}
\hline $\begin{array}{l}\text { Principal } \\
\text { descriptors }\end{array}$ & Levamisole & Aristolochic acid & Cleomiscosin-A & Cleomiscosin-B & Cleomiscosin-C & $\begin{array}{l}\text { (Range 95\% } \\
\text { of drugs) }\end{array}$ \\
\hline $\begin{array}{l}\text { Apparent MDCK } \\
\text { permeability }(\mathrm{nm} / \mathrm{sec})\end{array}$ & 5839 & 35 & 89 & 124 & 98 & $\begin{array}{l}\text { (<25 poor } \\
>500 \text { great })\end{array}$ \\
\hline $\begin{array}{l}\text { QP log Kp for skin } \\
\text { permeability }\end{array}$ & -3.392 & -3.608 & -3.669 & -3.307 & -3.558 & $\begin{array}{l}(-8.0 \text { to }-1.0 \\
\mathrm{Kp} \text { in } \mathrm{cm} / \mathrm{hr})\end{array}$ \\
\hline $\begin{array}{l}\text { Jm, max transdermal } \\
\text { transport rate }\end{array}$ & 0.028 & 0.058 & 0.023 & $0.04 I$ & 0.028 & $\begin{array}{l}\text { (micrograms/ } \\
\mathrm{cm}^{\wedge} 2-\mathrm{hr} \text { ) }\end{array}$ \\
\hline $\begin{array}{l}\text { Lipinski rule of } 5 \\
\text { violations }\end{array}$ & 0 & 0 & 0 & 0 & 0 & (maximum is 4) \\
\hline $\begin{array}{l}\text { Jorgensen rule of } 3 \\
\text { violations }\end{array}$ & 0 & 0 & 0 & 0 & 0 & (maximum is 3 ) \\
\hline $\begin{array}{l}\text { \% Human oral } \\
\text { absorption in GI }( \pm 20 \%)\end{array}$ & 100 & 74 & 78 & 81 & 80 & $\begin{array}{l}(<25 \% \text { is } \\
\text { poor) }\end{array}$ \\
\hline $\begin{array}{l}\text { Qual. model for } \\
\text { human oral absorption }\end{array}$ & $\mathrm{HIGH}$ & $\mathrm{HIGH}$ & $\mathrm{HIGH}$ & $\mathrm{HIGH}$ & $\mathrm{HIGH}$ & ( $>80 \%$ is high) \\
\hline
\end{tabular}

Note: *Indicates a violation of the $95 \%$ drug likeness range.

immune and inflammatory reactions. Immunomodulatory cytokines like IL-4, IL-10, and IL-13 are responsible for inhibiting the proinflammatory signaling and hence reduce inflammation. Recent advances in the studies of innate immunity have yielded better understanding of inflammatory mechanisms.

Toll-like receptors (TLRs) have been found to recognize and respond to the moieties related to tissue injury and microbial infections. ${ }^{17}$ TLRs are mediators of various cell mediated and humoral immune response caused by different agents or TLR specific ligands. Different TLRs have been found to respond to variety of pathogen-associated molecular pattern (PAMP) such as microbial agents, viral proteins, RNA, CpG DNA, bacterial lipopolysaccharides (LPS), and peptidoglycan. Signaling through TLRs results in inflammatory reactions mediated by various cytokines such as TNF- $\alpha$, IL-6, IL-8, and IL-1ß. The inhibitors of TLR mediated signaling of inflammatory reactions are the decoy receptors, signaling inhibitors, and immunomodulatory cytokines (IL-4, IL-10, and IL-13). ${ }^{13-18}$ Additionally, cluster of differentiation (CD) plays a very important role in the various immunological cascades of reactions and acts as a costimulatory signaling molecule for the activation of several lymphocytes. This activity is responsible for producing numerous immune responses such as production of T-helper cells, T-cytotoxic cells, macrophage activation, and antibody production. ${ }^{19-22}$ Results of molecular docking were comparable with the experimental results, ${ }^{4}$ which suggest that proinflammatory mediator expression was significantly decreased in the coumarinolignoids treatment group in dose dependent manner. This suggests that oral administration of coumarinolignoids inhibits the proinflammatory mediators and enhances the production of the immunomodulatory mediator (Table 5; Figures 4-6).

\section{Conclusion}

Molecular modeling calculations accompanied by in vivo experimental data on Swiss albino mice were used to predict potential immunomodulatory compounds among natural coumarinolignoids namely, cleomiscosin-A (1a), cleomiscosin-C (1f), and cleomiscosin-B (2a) isolated from C. viscosa seeds. The obtained results indicate that all studied compounds possess significant anti-inflammatory and immunomodulatory activity after oral administration and that cleomiscosin-B possess higher immunomodulatory activity comparable to standard drugs eg, Levamisole and cyclophosphamide. The QSAR analysis established the immunostimulatory activity of the cleomiscosin molecules in a dose dependent manner, which is in accord with the in vivo data. Results of molecular docking combined with in vivo data for inhibition of the human proinflammatory mediators suggest that compound cleomiscosin-B is preferentially more active than others with strong binding affinity to most of the immuno-modulatory receptors.

Table 5 Molecular docking based identification of potential immunomodulatory targets of cleomiscosin molecules

\begin{tabular}{ll}
\hline Coumarinolignoids & Potential target \\
\hline Cleomiscosin A (Ia) & TLR-4 \\
Cleomiscosin B (2a) & iNOS, COX-2, CDI4, IKK B \\
Cleomiscosin C (If) & CD86, COX-I \\
\hline
\end{tabular}




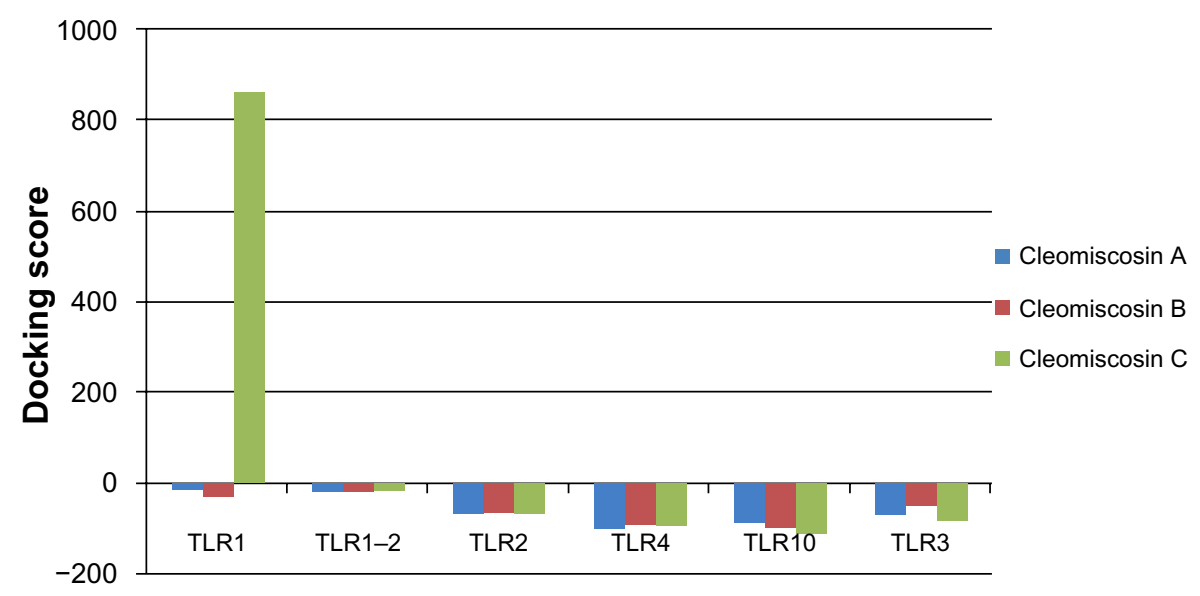

Figure 4 Binding affinity of cleomiscosin A, B, and C against toll-like receptors (TLRs). Docking scores (kcal/mol) in negative are acceptable.

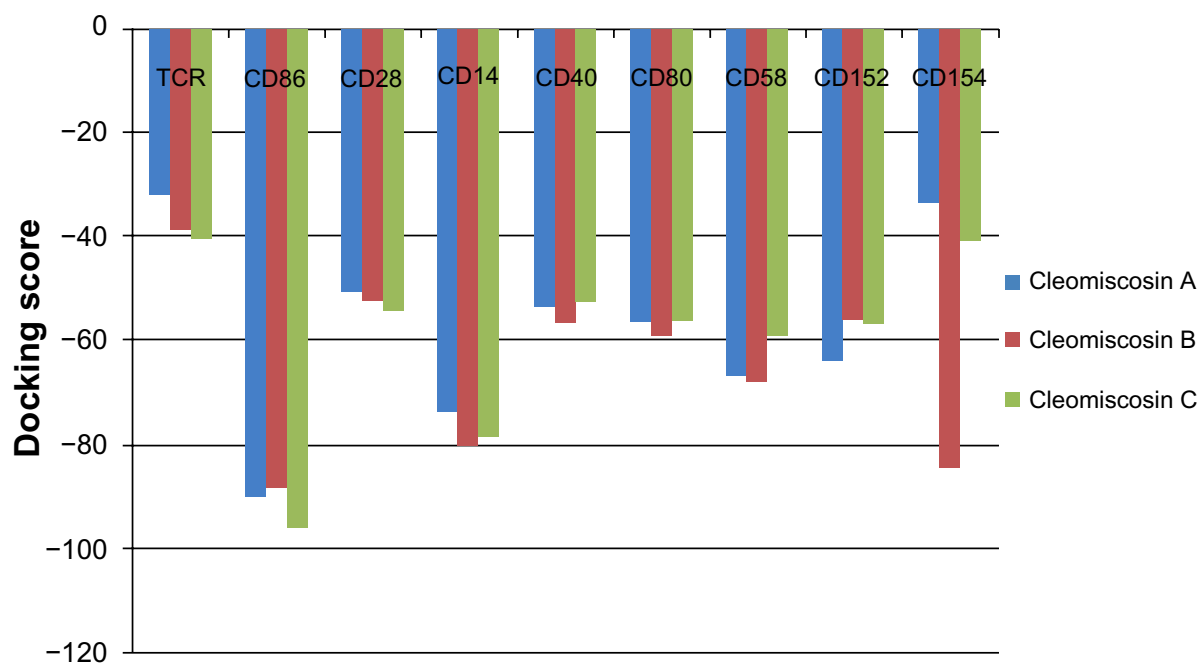

Figure 5 Binding affinity of cleomiscosin A, B, and C with various cluster of differentiation molecules (CD molecules) and T-cell receptor proteins. Negative docking scores $(\mathrm{kcal} / \mathrm{mol})$ are acceptable.

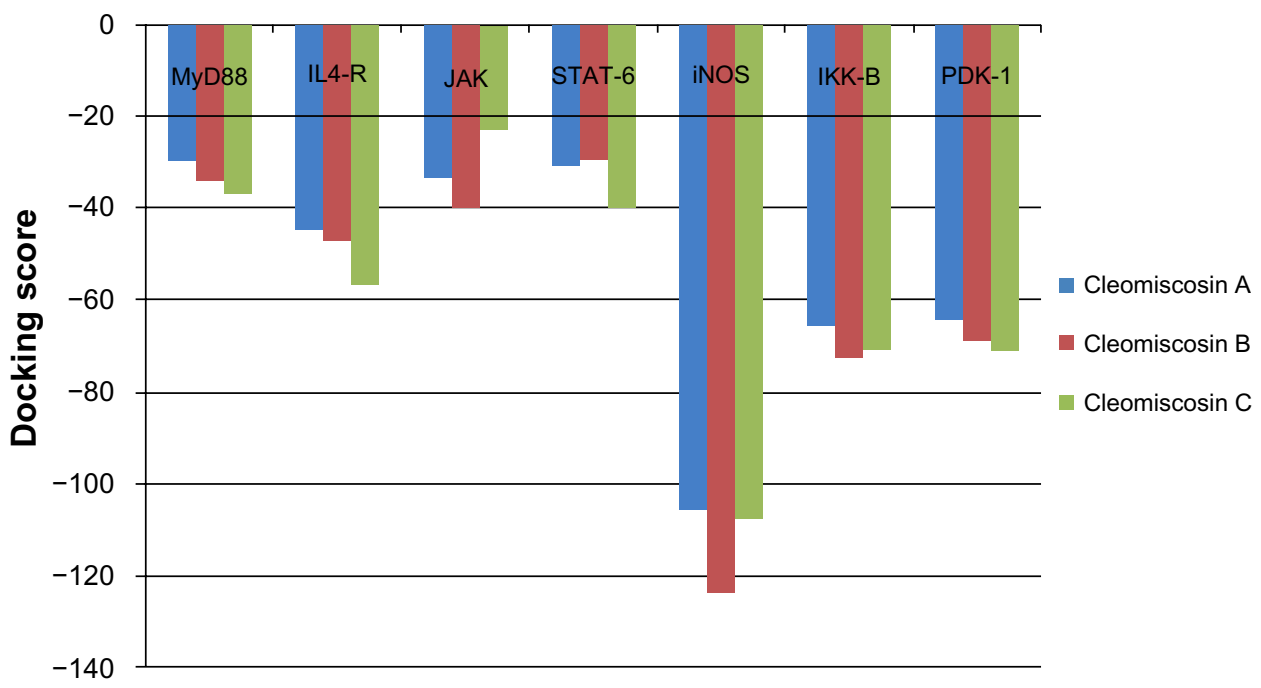

Figure 6 Binding affinity of cleomiscosin A, B, and C with various immune reaction cascade proteins and inducible nitric oxide synthase (iNOS) protein. Negative docking scores $(\mathrm{kcal} / \mathrm{mol})$ are acceptable. 


\section{Disclosure}

The authors acknowledge the Council of Scientific and Industrial Research, New Delhi, Network Project-09 (CSIR-NWP-09), for financial support at Central Institute of Medicinal and Aromatic Plants, Lucknow, India.

\section{References}

1. Patwardhan B, Warude D, Pushpangadan P, Bhatt N. Ayurveda and traditional Chinese medicine: a comparative overview. Ev-based Comp Alt Medicine. 2005;2(4):465-473.

2. Wagner H. Search for plant derived natural products with immunostimulatory activity (recent advances). Pure and Appl Chem. 1990;62(7):1217-1222.

3. Ray AB, Chattopadhyay SK, Konno SKC, Kiso Y, Hikino H. Structures of cleomiscosins, coumarinolignoids of Cleome viscosa seeds. Tetrahedron. 1985;41:209-214.

4. Bawankule DU, Chattopadhyay SK, Pal A, et al. Modulation of inflammatory mediators by coumarinolignoids from Cleome viscosa in female Swiss albino mice. Inflammopharm. 2008;16:1-6.

5. Chattopadhyay SK, Uniyal GD, Chattopadhyay SK, et al. Analysis of taxol and major taxoids in Himalayan yew, Taxus wallichiana. J Chromatography. 1999;858:239-244.

6. Muegge I. A knowledge-based scoring function for protein-ligand interactions: probing the reference state. Perspec Drug Dis Des. 2000;20:99-114.

7. Martin C. A general and fast scoring function for proteinligand interactions: a simplified potential approach. $J$ Med Chem. 1999;42:791-804.

8. Dilber SP, Dobric SL, Juranic ZD, Markovic BD, Vladimirov SM, Juranic IO. Docking studies and anti-inflammatory activity of ß-Hydroxy-ß-arylpropanoic acids. Molecules. 2008;13:603-615.

9. Lipinski CA, Lombardo F, Dominy BW, Fenney PJ. Experimental and computational approaches to estimate solubility and permeability in drug discovery and development settings. Adv Drug Deliv Rev. 2001;46:3-26.

10. Norinder U, Österberg T, Artursson P. Theoretical calculation and prediction of intestinal absorption of drugs in humans using MolSurf parameterization and PLS statistics. Eur J Pharm Sci. 1999;8:49-56.
11. Ertl P, Rohde B, Selzer P. Fast calculation of molecular polar surface area as a sum of fragment based contributions and its application to the prediction of drug transport properties. J Med Chem. 2000:43: 3714-3717.

12. Muzio M, Bosisio D, Polentarutti N, et al. Differential expression and regulation of toll-like receptors (TLR) in human leukocytes: selective expression of tlr 3 in dendritic cells. The J Immunology. 2000;164:5998-6004.

13. Kariko K, Weismann D, Welsh FA. Inhibition of toll-like receptor and cytokine signaling-a unifying theme in ischemic tolerance. $J$ Cereb Blood Flow and Metab. 2004;24:1288-1304.

14. Selzman CH. Ovarian ablation alone promotes aortic intimal hyperplasia and accumulation of fibroblast growth factor. Ann Thorac Surg. 1998;98:2049-2054.

15. Williams G, Giroir BP. Regulation of cytokine gene expression: tumor necrosis factor, interleukin-1, and the emerging biology of cytokine receptors. New Horiz. 1995;3:276-287.

16. Sasaki T, Soh H, Kimura T, Hasegawa T, Okada A, Fukuzawa M. Recurrent acute pancreatitis caused by malrotation of the intestine and effective treatment with laparoscopic Ladd's procedure. Pediatr Surg Int. 2005;21:994-996.

17. Philbinl VJ, Levy O. Immunostimulatory activity of Toll-like receptor 8 agonists towards human leucocytes: basic mechanisms and translational opportunities. Biochem Soc Trans. 2007;35:1485-1497.

18. Rachmilewitz D, Katakura K, Karmeli F, et al. Toll-like receptor 9 signaling mediates the immuno-modulatory effects of probiotics in murine experimental colitis. Gastroent. 2004;126:520-528.

19. Matthew JF, Douglas TG. LPS-binding proteins and receptors. J Leukocyte Biol. 1998;64:25-32.

20. Karyn S, Eisfelder BJ, Williamson E, Kabak S, Clark MA. Cutting edge: signals from the B lymphocyte antigen receptor regulate MHC class II containing late endosomes. J Immunol. 1998;160:5203-5208.

21. Keya S, Mambula SS, Latz E, et al. The antifungal drug amphotericin B promotes inflammatory cytokine release by a toll-like receptor-and CD14-dependent mechanism. J Biol Chem. 2003;278:37561-37568.

22. Nirula A, Ho M, Phee H, Roose J, Weiss A. Phosphoinositide-dependent kinase 1 targets protein kinase $\mathrm{A}$ in a pathway that regulates interleukin 4. J Exp Med. 2006;203:1733-1744.

23. Yoshida F, Topliss JG. QSAR model for drug human oral bioavailability. J Med Chem. 2000;43(13):2575-2585. 


\section{Appendix}

Appendix I List of training data set of drugs/compounds used in QSAR modeling. Anti-inflammatory and immuno-stimulatory drugs/compounds. Asterisk mark indicates that compounds retrieved from PubChem database, NCBI, USA (www.pubchem. ncbi.nlm.nih.gov)

\begin{tabular}{lll}
\hline S No. & Compound & $\begin{array}{l}\text { Reference* } \\
\text { (PubChem ID) }\end{array}$ \\
\hline I. & Aristolochic acid & CID: 2236 \\
2. & Cichoric acid & CID: 528 I764 \\
3. & Indometacin & CID: 3715 \\
4. & Plumbagin & CID: 10205 \\
5. & Berberine & CID: 2353 \\
6. & Emetin & CID: 10219 \\
7. & Isopteropodin & CID: 122813 \\
8. & Bowellic acid & CID: 168928 \\
9. & Gelsemin & CID: 6713959 \\
10. & Azimexon & CID: 47294 \\
II. & Ciamexon & CID: 71759 \\
12. & Imemixon & CID: $6879 \mid$ \\
13. & Methyl inosin monophasphate & CID: 454158 \\
14. & Diethyl dithiocarbamate & CID: 28343 \\
15. & Levamisol & CID: 26879 \\
16. & Urushiol & CID: 5478166 \\
17. & Ubiquinone & CID: 4462 \\
18. & Saikosaponin & CID: II9689I2 \\
19. & Tabernanthine & CID: 442136 \\
20. & Helenalin & CID: 23205 \\
\hline
\end{tabular}

Appendix 2 List of training data set of drugs/compounds used in QSAR modeling. Immuno-suppressive drugs/compounds

\begin{tabular}{|c|c|c|}
\hline S No. & Drug/compound & Reference \\
\hline I. & 5-Fluorouracil & Drug bank database \\
\hline 2. & Cytarabine hydrochloride & Drug bank database \\
\hline 3. & Busulfan & Drug bank database \\
\hline 4. & Thalidomide & Drug bank database \\
\hline 5. & Saikosaponin & $\begin{array}{l}\text { http://articles.directorym.com/ } \\
\text { chai_hu_-a853270.html }\end{array}$ \\
\hline 6. & Methyl cellosolve & Drug bank database \\
\hline 7. & Butenolide & $\begin{array}{l}\text { Moniliformin and butenolide: } \\
\text { effect on mice of high-level, } \\
\text { long-term oral intake pdf }\end{array}$ \\
\hline 8. & Methoxyacetic acid & Drug bank database \\
\hline 9. & Carboxylic acid & $\begin{array}{l}\text { http://www.maximpowercorp. } \\
\text { com/_pdf/deerland\%20project/ } \\
\text { alberta\%20environment/ } \\
\text { EPEAdeerlandapplication_ } \\
\text { appendix\%20G_I6oct07.pdf }\end{array}$ \\
\hline 10. & Azodicarbonamide & $\begin{array}{l}\text { http://www.sciencelab. } \\
\text { com/xMSDS- } \\
\text { azodicarbonamide_F_C_C- } \\
9922989\end{array}$ \\
\hline 11. & $\begin{array}{l}\text { Cyclophosphamide } \\
\text { monohydrate }\end{array}$ & $\begin{array}{l}\text { http://www.sciencelab.com/ } \\
\text { xMSDS-cyclophosphamide_- } \\
\text { monohydrate- } 9923635\end{array}$ \\
\hline
\end{tabular}

(Continued)

Appendix 2 (Continued)

\begin{tabular}{lll}
\hline S No. & Drug/compound & Reference \\
\hline 12. & Gemcitabine/gemzar & http://www.flexyx.com/g/ \\
& & gemcitabine\%20hcl.html
\end{tabular}

13. Rapamycin (sirolimus) www.fermentek.co.il/MSDS/

rapamycin-MSDS.htm

14. Tacrolimus fujimycin Drug bank database

15. Melphalan

16. Dimethyl sulphate

17. Thalidomide

18. Radanil/benznidazol

Drug bank database

www.chembargains.com/ attachfile/msds-100234.doc

http://msds.chem.ox.ac.uk/TH/ thalidomide.html

http://wisda.pharmazie. uni-marburg. de/index. html?http\&\&\&wisda.pharmazie. uni-marburg. de/dossier e.php?s_inn=benznidazol

19. Mizoribine

20. Nitrosodimethyl urea

21. Azaserine

22. Thiotepa

23. Cytarabine hydrochloride

24. Cytarabine/cylocide

25. Cytoxan

26. Coformycin (deoxy-coformycin)

27. Thioinosine

28. Leflunomide

29. Dibutyltin dichloride

30. Azathioprine/imuran

31. Mycophenolate mofetil

32. Triamcinolone acetonide

33. Lantadin/deflazacort http://www.msdshazcom.com/ web_docs/emd/doc/wcd00008/ wcd008a9.pdf

http://hazard.com/msds/tox/f/ q140/q 167.html http://www.msdshazcom.com/ WEB_DOCS/EMD/docs/ wcd0000b/wcd00b3d.pdf http://wfldelearn.pssd. com/binderview_PSS/ vault/00I/00I I00.pdf. In the search for new anticancer drugs/Sosnovsky G, Li SW http://msds.chem.ox.ac.uk/CY/ cytarabine_hydrochloride.html http://www.labseeker.com/ chemicalbiotech/chemmoreinfo. asp? catalog_ no $=21384$ http://www.pfeist.net/ALL/ cytoxan.html

Purine metabolism in adenosine deaminase deficiency chapter authors: H Anne Simmonds, A Sahota, CF Potter, D Perrett, $K$ Hugh-Jones, JG Watson http://www.coleparmer.in/ catalog/msds/26568.htm Drug bank database http://www.aladdin-reagent. $\mathrm{com} / \mathrm{msds} / 18969 . \mathrm{htm}$

Drug bank

Drug bank http://msds.chem.ox.ac.uk/TR/ triamcinolone_acetonide.html http://www.labseeker. com/cn/chemicalbiotech/ chemmoreinfo.asp? catalog no $=23945$

(Continued) 


\begin{tabular}{|c|c|c|}
\hline S No. & Drug/compound & Reference \\
\hline 34. & $\begin{array}{l}\text { D-amethopterin hydrate/ } \\
\text { D-methotrexate }\end{array}$ & $\begin{array}{l}\text { http://www.aladdinreagent. } \\
\text { com/msds/ I8362.htm }\end{array}$ \\
\hline 35. & Glimepiride & $\begin{array}{l}\text { http://wisda.pharmazie.uni- } \\
\text { arburg.de/ } \\
\text { http://www.labseeker.com/ } \\
\text { chemical biotech/chem-moreinfo. } \\
\text { asp?catalog_no = } 26445\end{array}$ \\
\hline 36. & Gusperimus & $\begin{array}{l}\text { themerckindex.cambridgesoft. } \\
\text { com/themercklndex/ } \\
\text { themerckIndex/reversed/ } \\
\text { M0004582.txt }\end{array}$ \\
\hline 37. & Ledertrexate & $\begin{array}{l}\text { http://www.flexyx.com/L/ } \\
\text { Ledertrexate.html }\end{array}$ \\
\hline 38. & Hexabutylditin oxide & $\begin{array}{l}\text { https://fscimage.fishersci.com/ } \\
\text { msds/08596.htm }\end{array}$ \\
\hline 39. & Tetrandrine & $\begin{array}{l}\text { Pharmacology and applications } \\
\text { of Chinese materia medica } \\
\text { books. Google.co.in/books? } \\
\text { Isbn } 981023692 \text { I }\end{array}$ \\
\hline 40. & Pheanthine & $\begin{array}{l}\text { http://www.chemdrug. } \\
\text { com/databases//3_0_ } \\
\text { vwdsmntgaekxfsfg.html } \\
\text { http://www.chemcas.com/msds/ } \\
\text { cas/msds87//263-79-2_v2.asp }\end{array}$ \\
\hline 41. & Methotrexate & Drug bank database \\
\hline
\end{tabular}

\section{List of chemical descriptors used in QSAR modeling}

1. Atom count (all atoms)

2. Bond count (all bonds)

3. Conformation minimum energy ( $\mathrm{kcal} / \mathrm{mole})$

4. Connectivity index (order 0 , standard)

5. Connectivity index (order 1, standard)

6. Connectivity index (order 2, standard)

7. Dipole moment (debye)

8. Dipole vector $\mathrm{x}$ (debye)

9. Dipole vector y (debye)

10. Dipole vector $z$ (debye)

11. Electron affinity (ev)

12. Dielectric energy ( $\mathrm{kcal} / \mathrm{mole})$

13. Steric energy ( $\mathrm{kcal} / \mathrm{mole})$

14. Total energy (Hartree)

15. Group count (aldehyde)

16. Group count (amide)

17. Group count (amine)

18. Group count (sec-amine)

19. Group count (carbonyl)

20. Group count (carboxyl)

21. Group count (carboxylate)
22. Group count (cyano)

23. Group count (ether)

24. Group count (hydroxyl)

25. Group count (methyl)

26. Group count (methylene)

27. Group count (nitro)

28. Group count (nitroso)

29. Group count (sulfide)

30. Group count (sulfone)

31. Group count (sulfoxide)

32. Group count (thiol)

33. Heat of formation $(\mathrm{kcal} / \mathrm{mole})$

34. HOMO energy $(\mathrm{eV})$

35. Ionization potential $(\mathrm{eV})$

36. Lambda max visible (nm)

37. Lambda max UV-visible (nm)

38. Lambda max far-UV-visible (nm)

39. Lambda max far-UV-visible (nm)

40. $\log \mathrm{P}$

41. LUMO energy (eV)

42. Molar refractivity

43. Molecular weight

44. Polarizability

45. Ring count (all rings)

46. Size of smallest Ring

47. Size of largest Ring

48. Shape index (basic kappa, order 1)

49. Shape index (basic kappa, order 2)

50. Shape index (basic kappa, order 3)

51. Solvent accessibility surface area (angstromsquare)

52. Formal charge

\section{Details of some important descriptors}

1. Molecular formula (MF): The molecular formula of the molecule.

2. Molecular weight (MW): The molecular weight of the molecule.

3. Log P: The octanol-water partition coefficient.

4. Solvent accessible surf area (SASA): The molecular surface area accessible to a solvent molecule.

5. Polarizability (P): The molecule's average alpha polarizability.

6. Shape index order 3 (SI3): A topological index quantifying the shape of a chemical sample. The shape index of order 3 (Kappa 3) quantifies the degree of branching toward the center of the chemical sample. 
7. Shape index order 2 (SI2): A topological index quantifying the shape of a chemical sample. The shape index of order 2 (Kappa 2) quantifies the degree of linearity or star-likeness of the chemical sample.

8. Shape index order 1 (SI1): A topological index quantifying the shape of a chemical sample. The shape index of order 1 (Kappa 1) quantifies the number of cycles in the chemical sample.

9. Largest ring size (LRS): The number of atoms forming the largest ring in the chemical sample, or 0 if the chemical sample contains no ring of size 12 or less.

10. Smallest ring size (SRS): Information about rings present in the compound. Rings with more than 12 atoms are ignored. The number of atoms forming the smallest ring in the compound, or 0 if the compound contains no ring of size 12 or less.

11. Ring count (RC): The number of rings present in the compound. Rings with more than 12 atoms are ignored. The number of rings with 12 or fewer atoms $($ All $=$ all aromatic, small, 5-membered, 5-membered aromatic, 6-membered, 6-membered aromatic, large, large aromatic).

12. Molar refractivity (MR): The molar refractivity of the compound.
13. LUMO energy: The energy gained when an electron is added to the lowest unoccupied molecular orbital (LUMO).

14. Lambda max far-UV-visible (LMFUV): The maximum absorption line in the far UV-visible spectrum (150-1000 nm).

15. Lambda max-UV-visible (LMUV): The maximum absorption line in the UV-visible spectrum (190-1000 nm).

16. Ionization potential (IP): The energy required to remove an electron from a molecule in its ground state.

17. HOMO energy: The energy required to remove an electron from the highest occupied molecular orbital (HOMO).

18. Heat of formation (HF): The energy released or used when a molecule is formed from elements in their standard states.

19. Conformation minimum energy (CME): Energy calculated for an optimized conformation of the compound.

20. Formal charge (FC): The net positive or negative charge on the molecule. Atom count (AC): The number of atoms.

21. Bond count (BC): The number of bonds. Weak and ionic bonds are ignored.
Drug Design, Development and Therapy

\section{Publish your work in this journal}

Drug Design, Development and Therapy is an international, peerreviewed open-access journal that spans the spectrum of drug design and development through to clinical applications. Clinical outcomes, patient safety, and programs for the development and effective, safe, and sustained use of medicines are a feature of the journal, which

\section{Dovepress}

has also been accepted for indexing on PubMed Central. The manuscript management system is completely online and includes a very quick and fair peer-review system, which is all easy to use. Visit http://www.dovepress.com/testimonials.php to read real quotes from published authors.

Submit your manuscript here: http://www.dovepress.com/drug-design-development-and-therapy-journal 